\title{
Pola Kuman dan Uji Kepekaan Antibiotik pada Sepsis Neonatorum di Unit Perawatan Neonatus RSUD dr. Pirngadi Kota Medan
}

\author{
Rasyidah \\ Departemen Ilmu Kesehatan Anak RSUD dr. Pirngadi Kota Medan
}

\begin{abstract}
Latar belakang. Sepsis neonatorum merupakan masalah utama dan penyebab kematian terbanyak di negara berkembang. Pemakaian antibiotik yang tidak tepat akan mengakibatkan resistensi kuman dan memperburuk kondisi pasien sehingga diperlukan data jenis kuman serta resistensinya terhadap antibiotik.

Tujuan. Mengetahui pola kuman dan uji kepekaan antibiotik pada pasien sepsis neonatorum di Unit Neonatus RSUD dr. Pirngadi Kota Medan.

Metode. Penelitian deskriptif mengambil data dari rekam medis pasien sepsis neonatorum dengan hasil kultur darah terbukti sepsis di Unit Neonatus RSUD Dr. Pirngadi Kota Medan sejak April 2010 sampai dengan April 2012. Data dianalisis menggunakan program SPSS 17.0. dengan tampilan frekuensi dan persentase.

Hasil. Didapat 129 neonatus dengan tersangka sepsis yang dilakukan kultur darah, 61 di antaranya terbukti sepsis, dua dieksklusi karena data rekam medis tidak lengkap sehingga didapat 59 subjek penelitian dengan 64,4\% laki-laki. Didapat $10(16,9 \%)$ neonatus meninggal. Jenis kuman yang terbanyak dijumpai adalah Enterobacter $s p(62,7 \%)$, diikuti Proteus $s p(27,1 \%)$, Klebsiella $s p(8,5 \%)$ dan Proteus vulgaris $(1,7 \%)$. Antibiotik seperti amikasin memiliki resistensi $40,7 \%$, ampisilin $83,1 \%$, sefotaksim $72,9 \%$, dan gentamisin $54,2 \%$ terhadap seluruh sampel yang diuji.

Kesimpulan. Penyebab sepsis neonatorum terbanyak adalah Enterobacter sp. Sebagian besar bakteri penyebab sepsis mempunyai resistensi yang tinggi terhadap ampisilin dan sefotaksim.
\end{abstract}

Sari Pediatri 2014;15(4):341-4.

Kata kunci: sepsis, pola kuman, resistensi

epsis neonatorum adalah sindrom klinis dengan gejala infeksi sistemik dan diikuti dengan bakteremia yang terjadi pada bulan pertama kehidupan. ${ }^{1.2}$ Insiden sepsis di negara

Alamat korespondensi:

Dr. Rasyidah, Sp.A. Staf Devisi Neonatologi RSUD dr. Pirngadi Kota Medan. Jl. Prof. H. Yamin SH No.47 Medan. Telp. (061) 4554891. Fax. (061) 4521223. Hp: 081361300021 E-mail:dr.rasyidah@yahoo.co.id berkembang masih cukup tinggi (1,8-18 kasus/1000 kelahiran) dibanding dengan negara maju (1-5 pasien/1000 kelahiran). ${ }^{3}$ Sepsis merupakan penyebab utama kematian neonatus dan di negara berkembang diperkirakan 30\%-50\%. Bakteri patogen penyebab sepsis berbeda antara satu negara dengan negara lain, ataupun antara satu rumah sakit dengan rumah sakit yang lain. ${ }^{3,4}$ Perbedaan pola kuman tersebut berdampak terhadap pemilihan terapi antibiotik. Pemakaian 
antibiotik yang tidak tepat akan mengakibatkan resistensi kuman dan memperburuk kondisi pasien sehingga diperlukan data jenis kuman serta resistensinya terhadap antibiotik.

\section{Metode}

Penelitian deskriptif dengan mengambil data secara retrospektif dari catatan medis pasien. Penelitian dilakukan di Sub Bagian Neonatologi RSUD Dr. Pirngadi Kota Medan dari April 2010 sampai April 2012. Kriteria inklusi semua neonatus tersangka sepsis dengan hasil biakan darah positif. Pasien dieksklusi apabila data rekam medis tidak lengkap. Data diolah dengan tampilan frekuensi dan persentase menggunakan program SPSS 17.0. Penelitian telah mendapat kelayakan etik dari Komite Etik penelitian RSUD dr. Pirngadi Kota Medan.

Kriteria tersangka sepsis apabila terdapat riwayat ibu dengan infeksi rahim, demam dengan kecurigaan infeksi berat atau ketuban pecah dini atau bayi mempunyai dua atau lebih gejala. Gejala seperti kesulitan bernafas, kejang, tidak sadar, suhu tubuh tidak normal, persalinan di lingkungan yang kurang higienis dan kondisi memburuk secara cepat dan dramatis, atau dijumpai 3 atau lebih gejala, seperti tremor, letargi, mengantuk, iritabel, muntah, perut kembung, tanda-tanda mulai muncul sesudah hari keempat, air ketuban bercampur mekonium, malas minum yang sebelumnya minum dengan baik. ${ }^{5}$

\section{Hasil}

Seratus duapuluh sembilan neonatus dengan tersangka sepsis yang dilakukan kultur darah, didapat 61 neonatus dengan biakan darah yang positif, dua pasien dieksklusi karena data rekam medis tidak lengkap sehingga didapat 59 subyek penelitian. Karakteristik subyek sebagian besar pasien adalah laki-laki (64,4\%), usia kehamilan kurang bulan $50,8 \%$ dan persalinan secara spontan $64.4 \%$ (Tabel 1). Didapat $16,9 \%$ pasien meninggal. Bakteri penyebab sepsis terbanyak adalah Enterobacter sp 62,7\%, diikuti Proteus sp 27,1\%, Klebsiella sp 8,5\% dan Proteus vulgaris 1,7\% .

Sebagian besar bakteri penyebab sepsis resisten $83,1 \%$ terhadap ampisilin, amikasin $40,7 \%$, genta-

Tabel 1. Karakteristik subyek

\begin{tabular}{lll}
\hline Karakteristik & $\mathrm{n}$ & $\%$ \\
\hline Jenis kelamin & & \\
$\quad$ Laki-laki & 38 & 64,4 \\
$\quad$ Perempuan & 21 & 35,6 \\
Berat badan lahir(gram) & & \\
$\quad \geq 2500$ & 26 & 44,1 \\
$\quad 1500-2499$ & 23 & 39,0 \\
$\quad 1500$ & 10 & 16,9 \\
$\quad$ Usia kehamilan & & \\
$\quad$ Kurang bulan & 30 & 50,8 \\
$\quad$ Cukup bulan & 29 & 49,2 \\
Cara persalinan & & \\
$\quad$ Spontan & 38 & 64,4 \\
$\quad$ Seksio sesaria & 21 & 35,6 \\
Keadaan pasien pulang & & \\
$\quad$ Hidup & 49 & 83,1 \\
$\quad$ Meninggal & 10 & 16,9 \\
\hline
\end{tabular}

Tabel 2. Jenis bakteri penyebab sepsis neonatorum

\begin{tabular}{lcc}
\hline Jenis bakteri & $\mathrm{n}$ & $\%$ \\
\hline Enterobacter $s$. & 37 & 62,7 \\
Proteus sp. & 16 & 27,1 \\
Klebsiella sp. & 5 & 8,5 \\
Proteus vulgaris & 1 & 1,7 \\
\hline
\end{tabular}

Tabel 3. Pola sensitifitas (S) dan resistensi (R) bakteri terhadap antibiotik

\begin{tabular}{lccccccccc}
\hline Antibiotik & \multicolumn{2}{c}{$\begin{array}{c}\text { Enterobacter sp } \\
(\%)\end{array}$} & \multicolumn{2}{c}{$\begin{array}{c}\text { Proteus sp. } \\
(\%)\end{array}$} & $\begin{array}{c}\text { Klebsiella sp. } \\
(\%)\end{array}$ & \multicolumn{2}{c}{$\begin{array}{c}\text { Proteus vulgaris } \\
(\%)\end{array}$} \\
\cline { 2 - 10 } & $\mathrm{S}^{*}$ & $\mathrm{R}^{*}$ & $\mathrm{~S}$ & $\mathrm{R}$ & $\mathrm{S}$ & $\mathrm{R}$ & $\mathrm{S}$ & $\mathrm{R}$ \\
\hline Ampisilin & 5,4 & 83,8 & 0 & 93,8 & 0 & 40 & 0 & 100 \\
Amikasin & 54,1 & 40,5 & 43,8 & 43,8 & 60 & 40 & 100 & 0 \\
Gentamisin & 32,4 & 56,8 & 6,25 & 62,5 & 80 & 0 & 0 & 100 \\
Kloramfenikol & 75,7 & 18,9 & 68,8 & 25 & 100 & 0 & 0 & 100 \\
Sefotaksim & 18,9 & 70,3 & 6,25 & 87,5 & 40 & 40 & 0 & 100 \\
\hline
\end{tabular}

Catatan: ${ }^{*} \mathrm{~S}=$ sensitif; $\mathrm{R}=$ resisten 
Rasyidah: Pola kuman dan uji kepekaan antibiotik pada sepsis neonatorum

misin 54,2\%, kloramfenikol 20,3\%, dan sefotaksim $72,9 \%$.

\section{Pembahasan}

Didapatkan hasil kultur darah positif subyek penelitian 47,3\%, hampir sama dengan data dari RS Cipto Mangunkosumo Jakarta 41,2\%, RSUP Sanglah Denpasar $48 \%$, dan di Iran $41 \%{ }^{6-8}$ Di India, didapat $26,9 \%$ hasil kultur darah positif, sedangkan di Nigeria $33,1 \%$. ${ }^{9}, 10$

Pada penelitian kami, bakteri penyebab sepsis terbanyak adalah Enterobacter $s p$ diikuti proteus $s p$, klebsiella sp dan proteus vulgaris. Penelitian sebelumnya di Iran, Enterobacter merupakan bakteri terbanyak (78,1\%) diikuti Klebsiella pneumonia (6,2\%), dan Escherichia coli (3,1\%). ${ }^{11}$ Penelitian di Pakistan, Staph. aureus merupakan bakteri terbanyak dijumpai (26,9\%) diikuti Escherichia coli (23,1\%), sedangkan di Philipina, Pseudomonas spp dijumpai 43,2\% diikuti Burkholderia spp 21,6\% dan Klebsiella spp. 10,8\%. ${ }^{12,13}$ Penelitian di San Fransisco didapatkan group B Streptococcus (GBS) adalah penyebab sepsis terbanyak (40,7\%), diikuti $E$ coli $(17,2 \%)$, dan Viridans streptococci $(16,4 \%) .{ }^{14} \mathrm{Di}$ Nigeria, dilaporkan bakteri terbanyak penyebab sepsis adalah Klebsiella pneumonia (65,4\%), Staphylococcus aureus $(15,4 \%)$, dan Escherichia coli $(7,7 \%) .{ }^{10}$ Penelitian sebelumnya di RSCM pada bulan Juli 2004 - Mei 2005, didapatkan Acinetobacter calcoacetius (35,67\%), Enterobacter sp (7,01\%), dan Staphylococcus $s p(6,8 \%)$ dan di Padang, didapatkan Staphylococcus aureus terbanyak penyebab sepsis diikuti Klebsiella $s p$ dan Enterrobacterr sp. ${ }^{15,16}$

Hasil uji resistensi dan sensitifitas terhadap sebagian besar bakteri penyebab sepsis, ampisilin memiliki resistensi $83,1 \%$ dan sensitifitas $3,4 \%$, sefotaksim resistensi $72,9 \%$, dan sensitifitas $16,9 \%$, gentamisin resistensi $54,2 \%$ dan sensitifitas $28,8 \%$, amikasin resistensi $40,7 \%$ dan sensitifitas $52,5 \%$ sedangkan kloramfenikol memiliki resistensi $20,3 \%$ dan sensitifitas $74,6 \%$. Pada penelitian ini kloramfenikol memiliki sensitiftas yang tinggi, tetapi antibiotik ini tidak digunakan pada neonatus, sedangkan ampisilin dan sefotaksim memiliki resistensi yang cukup tinggi. Di RS DR Moewardi di Surakarta, dilaporkan Enterobacter telah resisten terhadap ampisilin, sensitif terhadap Staphylococcus (12,5\%), dan Citrobacter (0\%), sedangkan terhadap gentamisin ketiga bakteri sudah resisten. ${ }^{17}$
Di RSCM Jakarta, Acinetobacter adalah bakteri penyebab terbanyak sepsis dan telah resisten terhadap ampisilin, sensitifitas gentamisin 33,3\% dan terhadap meropenem 100\%. ${ }^{6}$ Penelitian sebelumnya di Iran, didapatkan bakteri penyebab sepsis terbanyak adalah Klebsiella sp dan semuanya resisten terhadap ampisilin, sedangkan dengan meropenen sensitif 100\%. ${ }^{8}$ Pada penelitian kami, bakteri terbanyak Enterobacter $s p$ dan $83,3 \%$ resisten terhadap ampisilin diikuti sefotaksim $70,3 \%$.

\section{Kesimpulan}

Penyebab sepsis neonatorum terbanyak adalah Enterobactersp. Sebagian besar bakteri penyebab sepsis mempunyai resistensi yang tinggi terhadap ampisilin dan sefotaksim. Perlu dievaluasi untuk mengganti jenis antibiotik yang digunakan sebagai lini pertama dalam pengobatan sepsis neonatorum.

\section{Daftar pustaka}

1. Gomella Tl, Cunningham MD, Eyal FG. Sepsis. Dalam: Gomella TL, Cunningham MD, Eyal FG, penyunting. Neonatology Management, procedures, on-call problems, diseases, and drugs. Edisi ke-6. USA: Mcgraw-Hill; 2009.h.665-72.

2. Edward MS. Postnatal bacterial infections. Dalam: Fanaroff, Martins, penyunting. Neonatal-Perinatal Medicine. Edisi kedelapan. Philadelphia: Mosby Elsevier; 2006.h.791-804.

3. Gerdes JS. Diagnosis and management of bacterial infections in the neonate. Pediat Clin N Am 2004; 51:939-59.

4. Desinor OY, Silvia JL, Menos MJ. Neonatal sepsis and meningitis in Haiti. J Trop Pediatr 2004;50:48-50.

5. Pusponegoro HD, Hadinegoro SR, Firmanda D, Tridjaja B, Pudjiadi AH, Kosim MS, Rusmil K. Sepsis neonatorum. Dalam Pusponegoro HD, Hadinegoro SR, Firmanda D, Tridjaja B, Pudjiadi AH, Kosim MS, Rusmil K, penyunting. Standar Pelayanan Medis Kesehatan Anak . Edisi ke-1.Jakarta: Ikatan Dokter Anak Indonesia;2004.h.286-90.

6. Juniatiningsih A, Aminullah A, Firmansyah A. Profil mikroorganisme penyebab sepsis neonatorum di Departemen Ilmu Kesehatan Anak Rumah Sakit Cipto Mangunkusumo Jakarta. Sari Pediatri 2008;10:60-5. 
7. Kardana IM. Pola kuman dan sensitifitas antibiotik di ruang perinatologi. Sari Pediatri 2011;12:381-5.

8. Rad EM, Momtazmanesh. Neonatal sepsis due to klebsiella: frequency, outcome and antibiotic sensitivity. Iranian J Publ Health 2004;33:43-8

9. Mane AK, Nagdeo NV, thombare V.R. Study of neonatal septicemia in a tertiary care hospital in rural Nagpur. Journal of recent advances in applied sciences 2010;25:19-24.

10. Awoala WB, Nnenna TP. Clinico-bacteriological profile of early and late onset sepsis in a tertiary hospital in Nigeria. J Med Medical Science 2012;3:107-11.

11. Karambin MM, Zarkesh M. Enterobacter, the most common pathogen of neonatal septicemia in Rasht, Iran. Iran J Pediatr 2011;21:83-7.

12. Muhammad Z, Ahmed A, Hayat U, Wazir MS, Rafiyatullah, Waqas H. Neonatal sepsis: causative bacteria and their resistance to antibiotics. J Ayub Med Coll Abbottabad 2010;22:33-5.
13. Lazarte CC, Bunyi MA, GallardoEE, Lim JG, Lobo JJ, Aguilar CY. Etiology of neonatal sepsis in five urban hospitals in the Philippines. PIDSP Journal 2011;12:7585.

14. Hyde TB, Hilger TM, Reingold A, Farley MM, O’Brien KL, Schuchat A. Trends in incidence and antimicrobial resistance of early-onset sepsis: population-based surveillance in San fransisco and Atlanta. Pediatrics 2002;110:690-4.

15. Aminullah A. Masalah terkini sepsis neonatorum. Dalam: Update in neonatal infection. Departemen Ilmu Kesehatan Anak FKUI-RSCM;2005.h.1-15.

16. Mayetti, Imelda I. Pola bakteriologis dan uji sensitivitas pada sepsis neonatorum awitan dini. Sari Pediatri 2010;11:326-9.

17. Yulidar H, Martuti S, Sunyataningkamto. Pola kuman, sensitifitas antibiotik dan risiko kematian oleh kuman staphylococcus coagulase negatif pada sepsis neonatorum di RS DR Moewardi Surakarta. Sari Pediatri 2006;8:122-6. 